\title{
Economics of Phytoremediation with Biomass Production
}

\author{
Larry E. Erickson, Jan Černý, and Valentina Pidlisnyuk
}

\begin{abstract}
The economics associated with phytotechnologies includes environmental, social, and ecosystem costs and benefits associated with the project. There are local costs and benefits associated with the site as well as global benefits because of carbon sequestration. Improvements in soil quality have long-term benefits and increase the value of the land. Risk reduction has health and safety benefits as well as improved value for the land. For many contaminated sites, there are many benefits associated with phytoremediation with biomass production that have value for society such as improved aesthetic values, better conditions for wildlife, employment benefits because of the project, and better quality of life in the community. While it would be great if the biomass produced would fully cover project costs, this should not be expected. One of the most important benefits associated with phytotechnologies is the addition of soil organic matter and the associated improvements in the health of the biological populations that are beneficial to plant productivity. The economics of phytoremediation with biomass production using Miscanthus is included in this chapter.
\end{abstract}

\section{CONTENTS}

9.1 Introduction to Phytoremediation with Biomass Production ............... 160

9.2 Sustainable Approach ............................................................................. 160

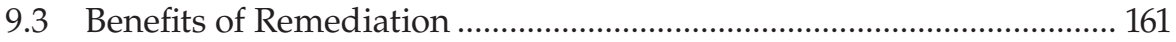

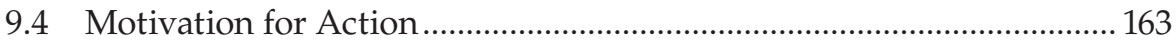

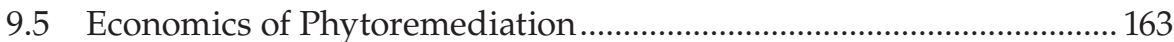

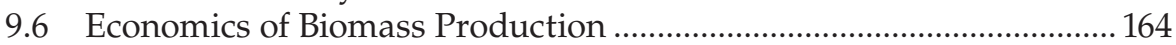

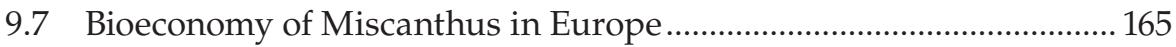

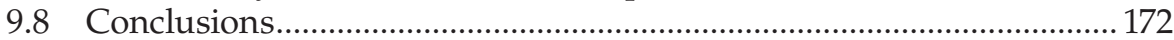

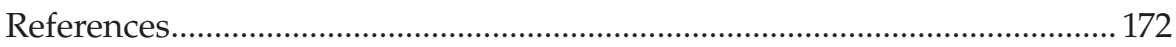




\subsection{Introduction to Phytoremediation with Biomass Production}

In this chapter, the economic aspects of phytoremediation with biomass production are addressed with full consideration of environmental, social, ecosystem, and economic benefits associated with the improvement of each contaminated site using a sustainable remediation approach. The benefits of soil remediation with biomass production include risk reduction, improvements in soil quality and soil health, biomass products, carbon sequestration, reduced soil erosion, community aesthetic benefits, and better habitat for birds and wild animals.

\subsection{Sustainable Approach}

When economic considerations are integrated with environmental impacts and social values, environmental metrics such as air quality, water quality, soil health, and ecosystem conditions are introduced. Social metrics of human health, quality of life, safety, aesthetic value, and impact on quality of employment can be considered. The economic analysis should include both direct and indirect costs and benefits.

The economics of greenhouse gas (GHG) emissions based on the avoided social cost of carbon is part of the sustainable approach. Increasing the amount of soil organic matter and soil organic carbon is beneficial in establishing vegetation, and this can be considered in the global carbon balance. In the majority of phytoremediation with biomass production projects, soil organic carbon will be increased and biomass will be produced. Policies that provide incentives to reduce GHG emissions or increase soil organic carbon may be included in the analysis (Mikhailova et al., 2019). The Paris agreement on climate change and those working to reduce GHG emissions have included initiatives to increase soil carbon as part of the Paris climate pledges (Paustian et al., 2019; Rumpel et al., 2018). The National Academies have described a new research agenda on carbon sequestration in soils to help achieve the goals of the Paris agreement (NASEM, 2019).

There are many sustainability indicators that have been proposed for use in a sustainable remediation framework (Bardos et al., 2018). The International Sustainable Remediation Alliance has been established to encourage networking among organizations and countries that are making use of sustainable approaches to remediation of contaminated sites (Bardos et al., 2018). One of the results of using sustainability indicators has been to find that qualitative methods often lead to simple sustainability assessments that produce good decisions that are supported by the participants. When working with 
community representatives, there is value in using methods and concepts that are understood by all participants, especially when this leads to a good remediation plan.

The System of Environmental Economic Accounting (SEEA) has been developed to include the value of ecosystems in evaluating contaminated sites; the system includes the ability to include soil quality and carbon sequestration in ecosystem accounting (Hein et al., 2020; SEEA, 2014). Natural capital has value for society, and there is a global effort to extend accounting to include the value of ecosystems so that site remediation benefits can be fully communicated.

\subsection{Benefits of Remediation}

The total amount of land with contaminated soil is great. Values in the literature include that $28.3 \%$ of the land area in Europe has soil contamination (Ben Fradj et al., 2020), and more than 20 million ha worldwide are contaminated (Evangelou et al., 2012). The estimated amount in the United States is about 9 million ha (U.S. EPA, 2011). In addition, there are between 1 and 6 billion ha of degraded soil that need to have soil organic matter added to improve soil quality and land productivity (Rumpel et al., 2018).

As population increases it becomes more important to remediate contaminated sites and use the land for beneficial purposes. There are many benefits associated with converting an unused contaminated site into a site that is used for biomass production. By addressing the contamination such that risk is reduced, the site can be used with vegetation to consume carbon dioxide and produce oxygen and plant biomass that can be used by society. Soil quality and soil health can be improved by adding soil amendments such as manure and/or biosolids from wastewater treatment to increase soil organic carbon.

There is value to establishing Miscanthus or another biomass crop on the site that produces a useful product and adds soil carbon to the root zone. Soil organic carbon improves nutrient cycling, the ecological functioning of the organisms in the root zone soil, and the water holding capacity of the soil (Lal, 2016). Better soil health is one of the major ecosystem benefits of phytoremediation with biomass production.

The increase in soil carbon in the root zone has value with respect to carbon sequestration for the global carbon balance and Paris agreement on climate change. At sites with metals in the soil, adding organic carbon to soil reduces the availability of the metals.

The benefits of phytoremediation include the aesthetic value of a green site that provides better habitat for native wildlife compared to the site prior to remediation. Ornamental vegetation can be used for phytoremediation where parks or arboretums are established for public use and enjoyment 
(Capuana, 2020). Phytoremediation reduces soil erosion and the spread of contaminants because of wind and water.

The social value of phytoremediation with biomass includes employment to carry out the remediation and to harvest the biomass. There would also be employment associated with the conversion of the biomass into products. The quality of life and safety near the site should be improved.

The economic costs and benefits include the costs associated with the phytoremediation with biomass production project. There are costs for site characterization, development of the remediation plan, and implementation of the plan. There are annual costs of caring for the site, harvesting the biomass, and selling the product. The annual income includes the net receipts for the biomass. There is economic value associated with the improved soil quality and the carbon sequestration, also.

The estimated value of the avoided social cost of carbon is $\$ 42.00 /$ metric ton of carbon dioxide (Mikhailova et al., 2019; U.S. EPA, 2016). This is the estimated global value of reducing GHG emissions in the form of carbon dioxide by 1 metric ton. This is an appropriate value to use when the social benefit of adding soil organic carbon to a remediation project is to be included in the analysis.

The concept of reducing GHG emissions by adding organic carbon to soil has received significant attention, and the idea has strong support (Lal, 2016; Mikhailova et al., 2019; NASEM, 2019).

There is value in improving soil quality at contaminated sites. Many of these sites have little or no economic value in their present state; however, if the soil can be improved by establishing vegetation and producing a biomass product such as Miscanthus or wood that can be harvested and sold, the value of the site increases. Since productive land sells for more than $\$ 10,000 /$ ha in many locations, one of the ecosystem benefits of phytoremediation with biomass production is the improvement in soil quality associated with the project. If one can remediate a contaminated site so that it can be used productively with products of the same quality as nearby farms, this is beneficial for society.

One way to improve the global carbon balance is to use phytoremediation with biomass production to establish trees on contaminated sites. Growing trees will increase soil carbon below ground and plant carbon above ground. At $\$ 42.00 /$ ton of carbon dioxide avoided, it may be beneficial to do this at many sites. The soil carbon below Miscanthus after $8-10$ years is about $90 \mathrm{MgC} \mathrm{ha}{ }^{-1}$ (Cattaneo et al., 2014; Dondini et al., 2009; Hansen et al., 2004), which adds about $\$ 13,860$ ha to the value of the project. Trees also have significant amounts of carbon in the soil and associated with their roots (Mikhailova et al., 2019). The amount of carbon added assumes that the site has very low soil carbon prior to the start of the remediation project.

The improvement in soil quality and the carbon added to the site are important ecosystem and economic reasons to go forward with phytoremediation projects. If one can move from the state of an abandoned site to one where a product is being produced, this has social value because of the employment that is created. 
The cost of reforestation to reduce the amount of carbon dioxide in the atmosphere of $\$ 1-\$ 10 /$ ton of carbon dioxide is relatively low compared to many alternatives (Gillingham \& Stock, 2018). If this is accomplished using phytoremediation at a contaminated site, land is restored to a productive use. In their work, they show that adding carbon to soil and aboveground vegetation is inexpensive compared to capturing carbon dioxide from combustion processes.

\subsection{Motivation for Action}

Vegetation is established at sites for several different reasons. Regulatory agencies may require land owners to reduce risk and/or contaminant movement due to wind and/or water erosion. Land owners may want to improve soil quality in order to use the land productively. There may be an interest to improve aesthetics and the quality of life in the neighborhood. A forest may be established to grow trees that benefit the global carbon balance and accumulate wood for future use.

The Tri-State Mining area in southeast Kansas, northeast Oklahoma, and southwest Missouri includes more than $80,000 \mathrm{ha}\left(800 \mathrm{~km}^{2}\right)$. While there has been some remediation, there is a need to do more phytostabilization to reduce risk and improve soil quality so the land can be used more productively. After the mining ended, there has been some research related to establishing vegetation on the mine tailings that are found in southeast Kansas. This abandoned mine land is a good example of a site where organic matter such as manure or biosolids need to be added to help establish vegetation. The motivation at this site includes risk reduction, carbon sequestration, better aesthetics, soil quality improvement, and future profitable use of the land.

There is a significant effort to meet the goals of the Paris agreement on climate change. Each contaminated site that is restored using phytoremediation with added soil carbon and productive vegetation contributes positively to the effort to stop the accumulation of carbon in the atmosphere. There are many good choices with respect to what to plant. Locally adapted vegetation should be considered. It is also important to improve the ecosystem at the site so more and better ecosystem services are able to be provided.

\subsection{Economics of Phytoremediation}

The global interest and significant use of phytoremediation is because of its low cost compared to other methods (Pivetz, 2001). There have been many sites where this technology has been used successfully. The cost of using 
vegetation is often less than half of that for alternative technologies (Fiorenza et al., 1999; McCutcheon \& Schnoor, 2004; Pivetz, 2001).

Phytoremediation has received much attention because the ecosystem at the contaminated site has generally been improved at sites where it has been implemented. The costs associated with growing vegetation are modest and supporting equipment is available because agriculture is global in its reach. Many people know how to grow plants and harvest produce.

The major costs associated with phytoremediation at field sites have often been associated with establishment of vegetation because amendments are needed to enable plants to grow at the site. The cost of amendments, moving them to the site, and incorporating them into the soil depend on the amount needed, distance transported, and process of incorporation into the soil at the site.

Analytical laboratory expenses can be one of the significant costs associated with phytoremediation. If the site is used for production of Miscanthus or to grow trees, the need for chemical analysis is reduced compared to growing food crops on the site. The analytical expense to characterize the contamination at the site is independent of the remediation method and often completed before a remediation method is selected.

\subsection{Economics of Biomass Production}

One of the goals of this book and the authors is to reduce the cost of remediation by producing products on contaminated sites that can be harvested and marketed. Miscanthus has significant biomass production and many potential uses. There has been great progress in developing Miscanthus as a crop to produce on contaminated sites. The economics of growing Miscanthus have been described in several publications (Hastings, 2017; Khanna et al., 2008; Witzel \& Finger, 2016). The cost of establishment of Miscanthus using rhizomes is expensive, and there is great interest in developing less expensive methods such as planting seeds (Ben Fradj et al., 2020; Hastings, 2017). Witzel and Finger (2016) have reviewed 51 economic studies of Miscanthus in Europe and North America. They point out that location and regional demand for the Miscanthus impact the economics. Biomass yields vary with soil quality and weather, and these factors affect the economics.

Miscanthus as harvested has a relatively low density, and this impacts transportation costs and the cost of delivery to markets. If it is used for bedding or as a solid fuel near to where it is produced, transportation costs are small. It can be pelleted to increase the density and make it easier to handle and transport.

Miscanthus has high-quality cellulose which has value in making some products; however, there are many sources of cellulose including trees, wheat straw, and switchgrass. Thus, the price for Miscanthus is related to the 
general price for biomass that contains cellulose. Paper products can be made from Miscanthus. Large quantities of biomass are used in many parts of the world for making many types of paper.

As greater efforts are made to reduce GHG emissions, more policies to encourage renewable sources of energy may be approved. If the combustion of coal would have a charge of $\$ 42 / \mathrm{Mg}$ of carbon dioxide added to it for each $M g$ = mega gram produced, this would make using Miscanthus biomass in a coal-fired power plant much more competitive because the cost of using coal would more than double in the USA.

Miscanthus and other biomass crops that may be produced using phytoremediation at a contaminated site can be used as feed to an anaerobic digester or as feed to an ethanol plant. The price of natural gas would be increased by about $\$ 2.19 /$ million BTUs if the $\$ 42 / \mathrm{Mg}$ carbon dioxide charge would be added. This value is $\$ 2.08 /$ million $\mathrm{kJ}$ using metric units. Adding this value to the price of natural gas makes methane from renewable sources much more competitive.

One approach to including the social value of carbon in decision-making would be to have a global carbon tax of $\$ 42 / \mathrm{Mg}$ carbon dioxide on mined fuels with the tax revenue used to support projects that add soil carbon to improve agriculture and restore contaminated sites using phytoremediation with biomass production.

\subsection{Bioeconomy of Miscanthus in Europe}

The modern bioenergy provided 5.1\% of total final energy demand in 2018, accounting for around half of all renewable energy in final energy consumption. Bioenergy provides around 9\% of industrial heat demand and is concentrated in bio-based industries such as paper and board. Biofuels, mostly ethanol and biodiesel, provide around 3\% of transport energy, and global biofuels production increased 5\% in 2019 (REN21, 2020).

The European Union (EU) is the global leader in modern bioenergy production. In 2011, EU reaffirmed its objective to reduce GHG emissions by $80 \%-95 \%$ by 2050 compared to 1990 levels (Communication from the Commission to the European Parliament, 2011; Zappa et al., 2019). The Europe 2020 (2010) strategy seeks to address structural weaknesses in the economies of EU individual member states, economic and social problems, and pressure to reduce the proportion of nonrenewable (fossil) fuels and replace them with renewable energy sources (RESs) in the overall energy mix (solar, wind, geothermal, hydropower, and biomass energy) which account about $14 \%$ of global energy production. In between 2000 and 2015 EU more than doubled the share of bioenergy in gross final energy consumption (Tsemekidi Tzeiranaki et al., 2020). EU 2030 strategy (2017) called for sharing of renewable energy in gross energy consumption for at least $32 \%$ by 2030 with annual growth 
of RES min 1.3\%, which will allow to go beyond EU commitment under the Paris Climate Agreement to reduce GHG emissions by at least $40 \%$ by 2030, compared to 1990 level (European Commission, 2019; RER 2030, 2019).

Germany is the largest producer of biomass which forms $23.6 \%$ of renewable electricity, and this share increased by $82.8 \%$ from 2008 to 2018 (Winkler et al., 2020). Providing sustainably produced feedstock for a growing bioeconomy is an important contribution to increase decarbonization of the German economy (Kiesel, 2020). In 2017 in the Czech Republic gross production of electricity from renewable sources accounted for $11.1 \%$ of the total domestic gross electricity production, and the share of renewable energy in primary energy sources was approximately 10.5\% in 2017 (Ministry of Industry and Trade of the Czech Republic, 2018).

Perennial crops appear to be ideal for EU bioeconomy development; however, their cultivation plays a minor role in EU agriculture, and only about 43,800 ha of agricultural land were used for their production in 2015 (Cosentino et al., 2018). It may be explained by uncertainties about the economic viability and financial returns of these relatively novel crops, the long-term allocation of agricultural land to their production, the high investment costs for initial establishment (Sherrington et al., 2008), and absent of markets for biomass from perennial crops, in particular, from Miscanthus (Lewandowski et al., 2016; Witzel \& Finger, 2016).

However, since 2018, Miscanthus has been included in the so-called "Greening" of the EU (Regulation (EU) 2017/2393), which might be advantageous for farmers to cultivate Miscanthus. In Central and Eastern Europe Miscanthus has a potential for bioenergy and bioeconomy (Dubis et al., 2019; Kvak et al., 2018; Tryboi, 2018). Biomass of this crop is becoming among important sources of energy in Ukraine (Roik et al., 2019) as country suffers from lack of imported fossil fuels and looks for substitution sources (Geletukha, 2017). By 2035 the share of renewable energy in the Ukrainian energy balance is expected to be $25 \%$, with essential input of bioenergy plants. Two types of energy crops are cultivated in Ukraine currently, fast-growing willow (79\%) and $M . \times$ giganteus (15\%) (Geletukha et al., 2016).

The comprehensive literature review (Witzel \& Finger, 2016) overviewed 51 scientific papers dealing with economics of Miscanthus cultivation to reveal the factors influencing the adoption decision of farmers. The most crucial factors for the profitability of Miscanthus and adoption decision of the farmer are diverse, including the following aspects: the expected lifespan, biomass yields, prices, establishment and opportunity costs, and subsidization possibilities. The large uncertainty is concerning the key parameters: yields and prices. Across 51 reviewed studies, mean yield assumptions ranged from 10 to $48 \mathrm{t}$ dry biomass ha ${ }^{-1}$ while the assumptions concerning mean prices range from $€ 48$ to $€ 134 /$ ton of dry mass. And absence of an established market for biomass is mentioned as a major impediment leading to increased market risks for Miscanthus feedstock. 
The perspective of bioenergy crop cultivation has to fulfill the following requirements (Von Cossel et al., 2019):

- providing a beneficial social and ecological contribution in increasing of agro-ecological biodiversity and landscape aesthetics;

- ensuring cultivation on marginal agricultural land or slightly contaminated land which allow to avoid competition with food crop production; bioenergy crops have to be able to cope with the given biophysical constraints on marginal agricultural lands;

- resilience of bioenergy cropping systems toward the growing climate change effect;

- fostering rural development and supporting the vast number of small-scale family farmers, managing some $80 \%$ of the global agricultural land and natural resources.

The production costs and labor requirement of Miscanthus cultivation and processing to bioproducts: animal bedding, combustion, and biogas were assessed recently (Winkler et al., 2020). The approach based on summarizing of the best practices of Miscanthus cultivation during multiyear production, including first year establishment phase, and harvest phase starting from the 2nd year till 20th year. The cultivation cost assessment with conversion to selected bioproducts is presented in Tables 9.1-9.3. The biggest investment is at the first year of plantation establishing from which the largest investment is for purchasing of rhizomes and labor cost. Another important cost driver is the field-to-farm distance. It was concluded (Winkler et al., 2020) that the implementation of Miscanthus into farming systems can be profitable in the following cases: (i) for lands with unfavorable conditions, such as awkward shapes, slopes, or low soil quality; (ii) for greening areas or soil protection corridor; (iii) when Miscanthus is directly used in own farm. Also profitable is to cultivate Miscanthus in smaller plantation up to $1 \mathrm{ha}$, and to utilize biomass for combustion, animal bedding, and anaerobic digestion, and from these three pathways production of animal bedding defined as the most reasonable (Winkler et al., 2020).

Miscanthus has a potential to play an important role to provide sustainably produced feedstock for the biogas sector (in short-term) and bioeconomy (in long-term) (Kiesel, 2020). It will assist to achieve net zero GHG emissions, since it can provide sustainably produced feedstock and a renewable carbon source for the chemical industry, which requires carbon for varieties of products. Miscanthus is suitable for biogas production, being more environmental in comparison with annual crops, may assist to decrease the environmental impact of the biogas sector. A market pull for Miscanthus biomass while utilized for biogas production may stimulate further investments into this crop. Development of integrated on-farm biorefineries for Miscanthus feedstock 


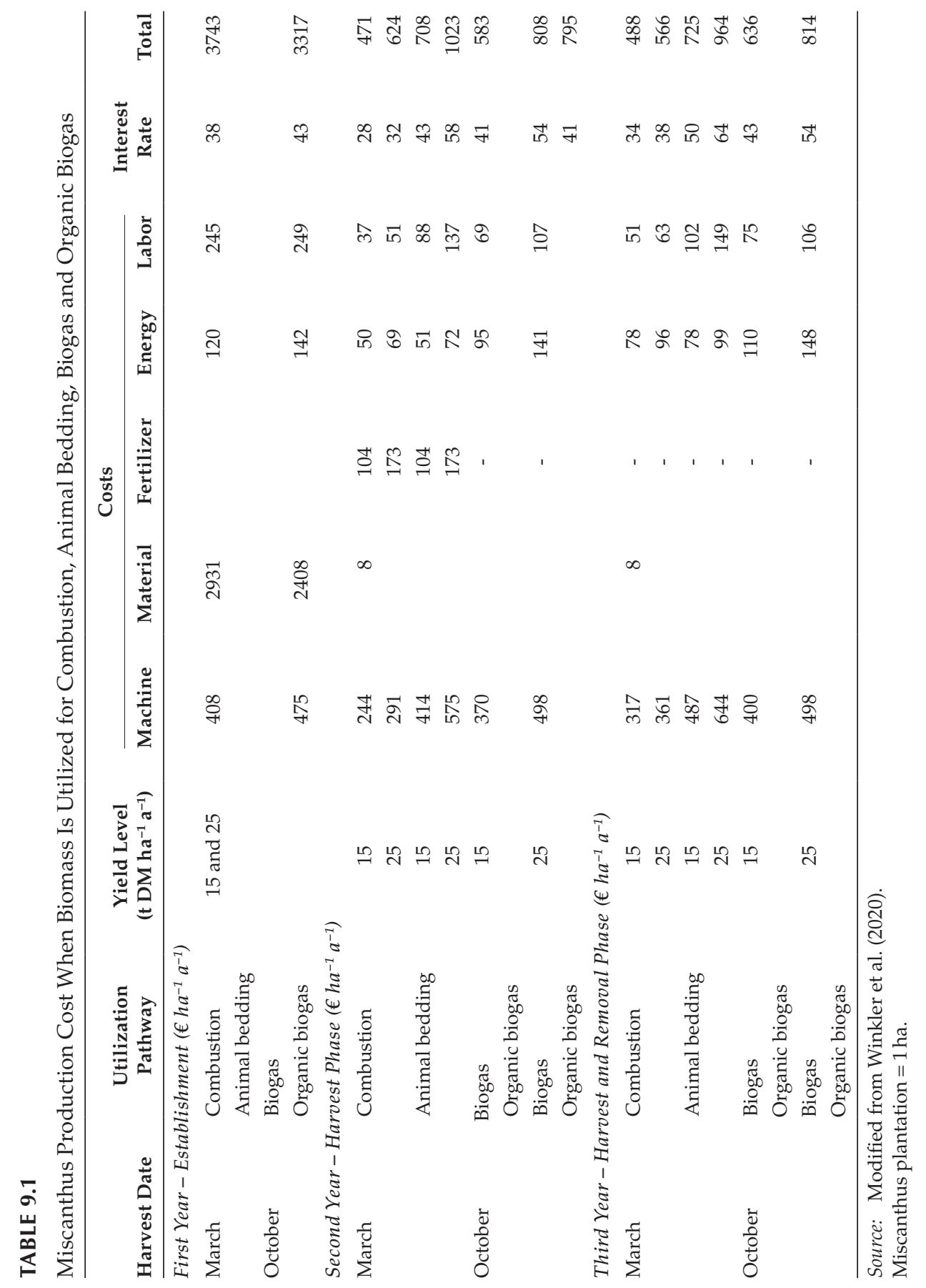




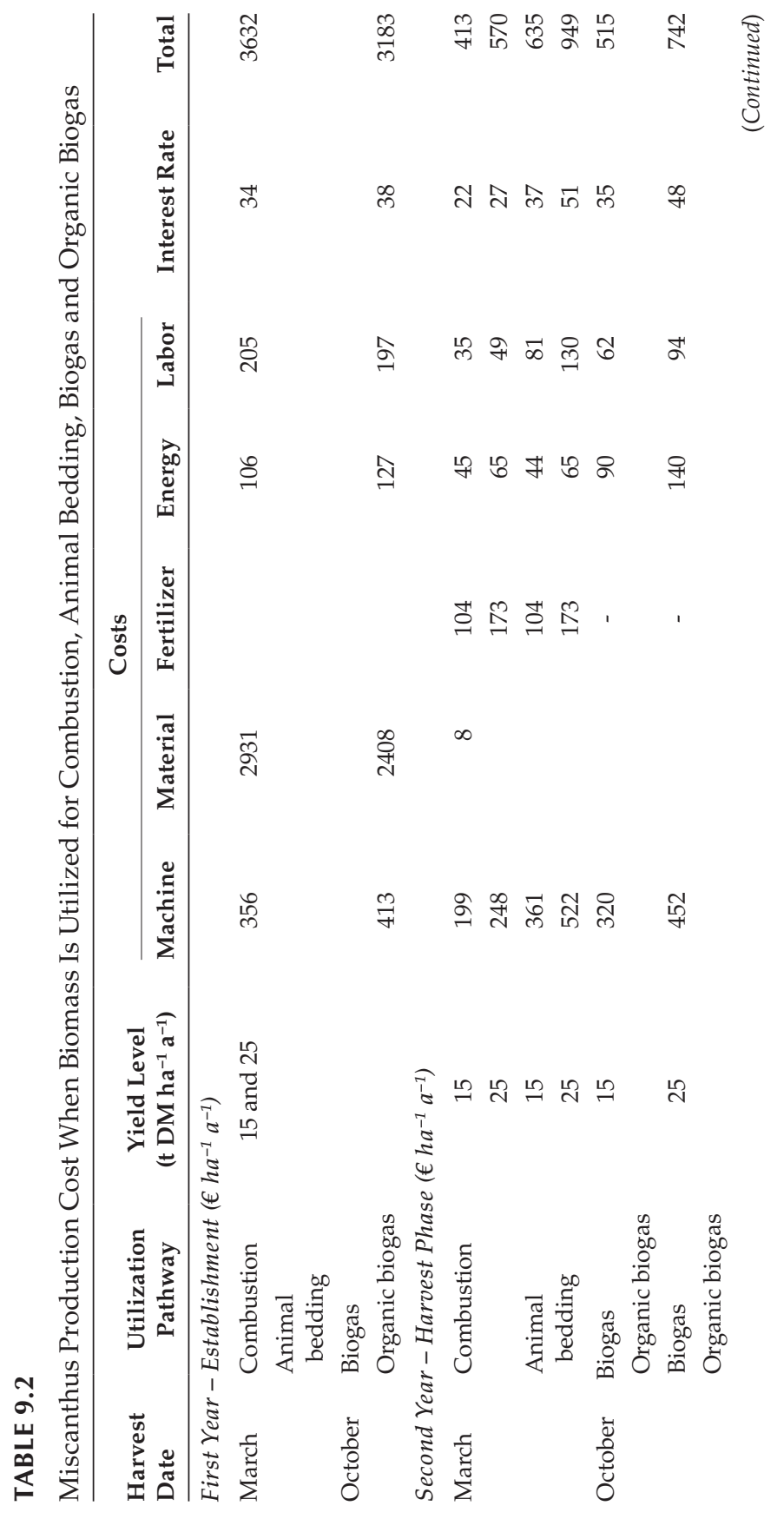




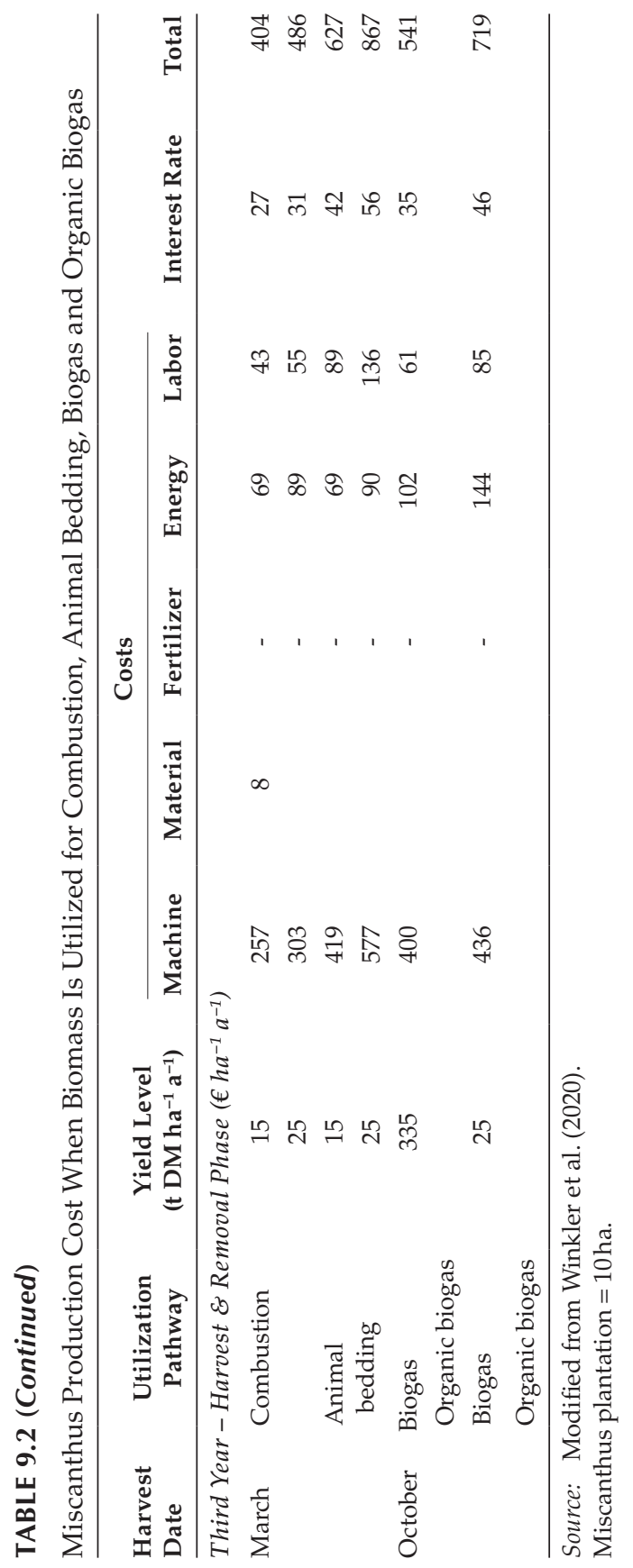




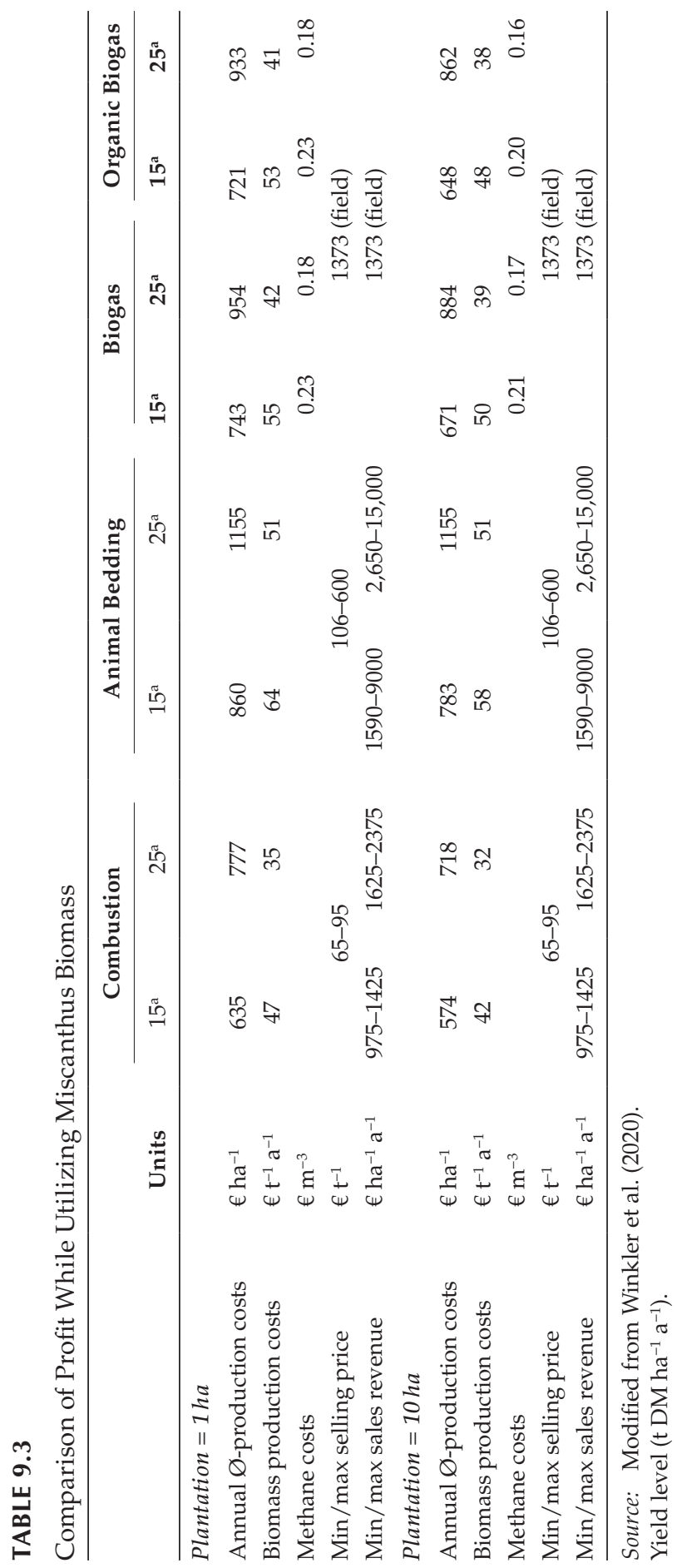


utilization and biogas production may be an attractive business model for farmers which simultaneously reduces environmental impacts of agriculture by decreasing cultivation of annual crops (Kiesel, 2020).

\subsection{Conclusions}

The benefits of phytoremediation of contaminated sites include siteimprovement, carbon sequestration, and biomass products. Because of the growing importance of land, greater efforts should be made to improve soil quality and reclaim abandoned properties. Environmental, social, and economic values should be considered in applying a sustainable development approach to making decisions using phytoremediation with biomass production.

\section{References}

Bardos, R., Thomas, H., Smith, J., Harries, N., Evans, F., Boyle, R., Howard, T., Lewis, R., Thomas, A., \& Haslam, A. (2018). The development and use of sustainability criteria in SuRF-UK's sustainable remediation framework. Sustainability, 10(6), 1781. https://doi.org/10.3390/su10061781.

Ben Fradj, N., Rozakis, S., Borzęcka, M., \& Matyka, M. (2020). Miscanthus in the European bio-economy: A network analysis. Industrial Crops and Products, 148, 112281. https://doi.org/10.1016/j.indcrop.2020.112281.

Capuana, M. (2020). A review of the performance of woody and herbaceous ornamental plants for phytoremediation in urban areas. IForest, 13(2), 139-151. https:// doi.org/10.3832/ifor3242-013.

Cattaneo, F., Barbanti, L., Gioacchini, P., Ciavatta, C., \& Marzadori, C. (2014). 13C abundance shows effective soil carbon sequestration in Miscanthus and giant reed compared to arable crops under Mediterranean climate. Biology and Fertility of Soils, 50(7), 1121-1128. https://doi.org/10.1007/s00374-014-0931-x.

Communication from the Commission to the European Parliament, the Council, the European Economic and Social Committee and the Committee of the Regions. (2011). A roadmap for moving to a competitive low carbon economy in 2050. European Commission, Brussels, European Union.

Cosentino, S. L., Scordia, D., Testa, G., Monti, A., Alexopoulou, E., \& Christou, M. (2018). The importance of perennial grasses as a feedstock for bioenergy and bioproducts. In Efthymia, A. (ed.), Perennial Grasses for Bioenergy and Bioproducts, 1-33. Elsevier, Amsterdam. https://doi.org/10.1016/b978-0-12-812900-5.00001-1.

Dondini, M., van Groenigen, K.-J., del Galdo, I., \& Jones, M. B. (2009). Carbon sequestration under Miscanthus: A study of $13 \mathrm{C}$ distribution in soil aggregates. GCB Bioenergy, 1(5), 321-330. https://doi.org/10.1111/j.1757-1707.2009.01025.x. 
Dubis, B., Jankowski, K. J., Załuski, D., Bórawski, P., \& Szempliński, W. (2019). Biomass production and energy balance of Miscanthus over a period of 11 years: A case study in a large-scale farm in Poland. GCB Bioenergy, 11(10), 1187-1201. https:// doi.org/10.1111/gcbb.12625.

Europe 2020. (2010). A strategy for smart, sustainable and inclusive growth. 35 p.

European Commission. (2019). Towards a sustainable Europe by 2030. 132 p. ISBN: 97892-79-98963-6. https://doi.org/10.2775/676251.

Evangelou, M. W. H., Conesa, H. M., Robinson, B. H., \& Schulin, R. (2012). Biomass production on trace element-contaminated land: A review. Environmental Engineering Science, 29(9), 823-839. https://doi.org/10.1089/ees.2011.0428.

Fiorenza, S., Oubre, C. L., \& Ward, C. H. (1999). Phytoremediation of HydrocarbonContaminated Soils (Vol. 2). CRC Press, Boca Raton, FL.

Geletukha, G. (2017). Development and prospects of bioenergy in Ukraine. International Conference of Biomass for Energy 2017, Kyiv, Ukraine, September $19-20$.

Geletukha, G., Zheliezna, T., Tryboi, O., \& Bashtovyi, A. (2016). Analysis of criteria for the sustainable development of bioenergy. UABio Position Paper, 17, 1-30.

Gillingham, K., \& Stock, J. H. (2018). The cost of reducing greenhouse gas emissions. Journal of Economic Perspectives, 32(4), 53-72. https://doi.org/10.1257/jep.32.4.53.

Hansen, E. M., Christensen, B. T., Jensen, L. S., \& Kristensen, K. (2004). Carbon sequestration in soil beneath long-term Miscanthus plantations as determined by $13 \mathrm{C}$ abundance. Biomass and Bioenergy, 26(2), 97-105. https://doi.org/10.1016/ S0961-9534(03)00102-8.

Hastings, A. (2017). Economic and Environmental Assessment of Seed and Rhizome Propagated Miscanthus in the UK. Frontiers in Plant Science, 8, 1058. https://doi. org/10.3389/fpls.2017.01058.

Hein, L., Bagstad, K. J., Obst, C., Edens, B., Schenau, S., Castillo, G., Soulard, F., Brown, C., Driver, A., \& Bordt, M. (2020). Progress in natural capital accounting for ecosystems. Science, 367(6477), 514-515. https://doi.org/10.1126/science.aaz8901.

Khanna, M., Dhungana, B., \& Clifton-Brown, J. (2008). Costs of producing miscanthus and switchgrass for bioenergy in Illinois. Biomass and Bioenergy, 32(6), 482-493. https://doi.org/10.1016/j.biombioe.2007.11.003.

Kiesel, A. (2020). The potential of miscanthus as biogas feedstock. PhD diss., University of Hohenheim, Germany. $145 \mathrm{p}$.

Kvak, V., Stefanovska, T., Pidlisnyuk, V., Alasmary, Z., \& Kharytonov, M. (2018). The long-term assessment of Miscanthus $\times$ gigantheus cultivation in the Forest-Steppe zone of Ukraine. INMATEH-Agricultural Engineering, 54(1), 113-120. https://doi. org/10.17707/AgricultForest.64.2.10.

Lal, R. (2016). Soil health and carbon management. Food and Energy Security, 5(4), 212-222. https://doi.org/10.1002/fes3.96.

Lewandowski, I., Clifton-Brown, J., Trindade, L. M., van der Linden, G. C., Schwarz, K.-U., Müller-Sämann, K., Anisimov, A., Chen, C.-L., Dolstra, O., Donnison, I. S., Farrar, K., Fonteyne, S., Harding, G., Hastings, A., Huxley, L. M., Iqbal, Y., Khokhlov, N., Kiesel, A., Lootens, P., \& Kalinina, O. (2016). Progress on optimizing Miscanthus biomass production for the European bioeconomy: Results of the EU FP7 Project OPTIMISC. Frontiers in Plant Science, 7(NOVEMBER), 1620. https://doi.org/10.3389/fpls.2016.01620.

McCutcheon, S. C., \& Schnoor, J. L. (2004). Phytoremediation: Transformation and Control of Contaminants (Vol. 121). John Wiley \& Sons, Hoboken, NJ. 
Mikhailova, E. A., Groshans, G. R., Post, C. J., Schlautman, M. A., \& Post, G. C. (2019). Valuation of soil organic carbon stocks in the contiguous United States based on the avoided social cost of carbon emissions. Resources, 8(3), 153. https://doi. org/10.3390/resources8030153.

Ministry of Industry and Trade of the Czech Republic. (2018). Obnovitelné zdroje energie v roce 2017. Retrieved from: https://www.mpo.cz/assets/cz/energetika/statistika/obnovitelne-zdroje-energie/2018/12/Obnovitelne-zdrojeenergie-v-roce-2017-new.pdf.

NASEM. (2019). Negative Emissions Technologies and Reliable Sequestration: A Research Agenda. National Academy of Sciences, Engineering and Medicine, The National Academies Press, Washington, DC.

Paustian, K., Larson, E., Kent, J., Marx, E., \& Swan, A. (2019). Soil C sequestration as a biological negative emission strategy. Frontiers in Climate, 1(8), 8. https://doi. org/10.3389/fclim.2019.00008.

Pivetz, B. E. (2001). Phytoremediation of contaminated soil and ground water at hazardous waste sites. US Environmental Protection Agency EPA/540/S-01/500, Office of Research and Development.

REN21. (2020). Renewables 2020 Global Status Report. REN21 Secretariat, Paris. ISBN 978-3-948393-00-7.

RER 2030. Renewable Energy - Recast to 2030. (2019). EU Science Hub: The European Commission's science and knowledge service. European Union. https://ec.europa. eu/jrc/en/jec/renewable-energy-recast-2030-red-ii.

Roik, M. V., Sinchenko, V. M., Ivaschenko, O. O., Purkin, V. I., Kvak, V. M., Gumentik, M. Ya., Ganzhenko, O. M., Sabluk, V. T., Grischenko, O. M., Fuchilo, Ya. D., Goncharuk, G. S., Furman, V. A., Kocar, M. I., Cvigun, G. V., Kovalchuk, N. S., Nedyak, T. M., Vorozhko, S. P., Doronin, V. A., Driga, V. V., Buzinnii, M. V., Dubovii, U. P., Pedos, V. P., Balagura, O. V., Smirnih, V. M., Zaimenko, N. V., Rahmetov, D. B., Scherbakova, T. O., Rahmetov, S. D., \& Katelevskii, V. M. (2019). Miscanthus in Ukraine. Kyiv, Ukraine: FOP Yamchinskiy Press. ISBN 978-6177804-11-5 [in Ukrainian].

Rumpel, C., Amiraslani, F., Koutika, L.-S., Smith, P., Whitehead, D., \& Wollenberg, E. (2018). Put more carbon in soils to meet Paris climate pledges. Nature, 564, 32-34.

Sherrington, C., Bartley, J., \& Moran, D. (2008). Farm-level constraints on the domestic supply of perennial energy crops in the UK. Energy Policy, 36(7), 2504-2512. https://doi.org/10.1016/j.enpol.2008.03.004.

System of Environmental-Economic Accounting. (2014). System of Environmental-Economic Accounting 2012: Experimental Ecosystem Accounting. United Nations, New York.

Tryboi, O. V. (2018). Efficient biomass value chains for heat production from energy crops in Ukraine. Energetika, 64(2), 84-92. https://doi.org/10.6001/energetika. v64i2.3782.

Tsemekidi Tzeiranaki, S., Bertoldi, P., Paci, D., Castellazzi, L., Serrenho, T., Economidou, M., \& Zangheri, P. (2020). Energy consumption and energy efficiency trends in the EU-28, 2000-2018. EUR 30328 EN, Publications Office of the European Union, Luxembourg, 156 p., ISBN 978-92-76-21074-0. https://doi.org/10.2760/847849. JRC120681.

U.S. EPA. 2011. Handbook on the Benefits, Costs, and Impacts of Land Cleanup and Reuse. U.S. Environmental Protection Agency, Washington, DC.

U.S. EPA. 2016. The Social Cost of Carbon. EPA Fact Sheet, 2016. U.S. Environmental Protection Agency, Washington, DC. 
Von Cossel, M., Wagner, M., Lask, J., Magenau, E., Bauerle, A., Von Cossel, V., WarrachSagi, K., Elbersen, E., Staritsky, I., Van Eupen, M., Iqbal, Y., Jablonowski, N. D., Happe, S., Fernando, A. L., Scordia, D., Cosentino, S. L., Wulfmeyer, V., Lewandowski, I., \& Winkler, B. (2019). Prospects of bioenergy cropping systems for a more social-ecologically sound bioeconomy. Agronomy, 9(10), 605. https:// doi.org/10.3390/agronomy9100605.

Winkler, B., Mangold, A., von Cossel, M., Clifton-Brown, J., Pogrzeba, M., Lewandowski, I., Iqbal, Y., \& Kiesel, A. (2020). Implementing miscanthus into farming systems: A review of agronomic practices, capital and labour demand. Renewable and Sustainable Energy Reviews, 132, 110053. https://doi.org/10.1016/j. rser.2020.110053.

Witzel, C. P., \& Finger, R. (2016). Economic evaluation of Miscanthus production A review. Renewable and Sustainable Energy Reviews, 53, 681-696. https://doi. org/10.1016/j.rser.2015.08.063.

Zappa, W., Junginger, M., \& van den Broek, M. (2019). Is a 100\% renewable European power system feasible by 2050? Applied Energy, 233-234, 1027-1050. https://doi. org/10.1016/j.apenergy.2018.08.109. 